\title{
Air Pollution Control Act
}

Original 21 articles promulgated by presidential order on May 23, 1975

Eighty-six articles revised and promulgated by presidential order on June 19, 2002

Article 18 revised and promulgated by presidential order on May 18, 2005

Articles 59 and 86 revised and promulgated by presidential order on May 30, 2006

\section{Chapter 1 General Principles}

\section{Article 1}

This Act is formulated to control air pollution, maintain public health and the living environment and improve the quality of life.The regulations of other laws shall apply to those matters not regulated by this Act.

\section{Article 2}

Terms used in this Act are defined as follows.

I. Air pollutant means an airborne substance sufficient to jeopardize directly or indirectly public health or the living environment.

II. Pollution source means a physical or chemical operating unit that emits air pollutants.

III. Motor vehicle means a vehicle that travels on a roadway under its own power and that is not dependent on rail or electric power systems.

IV. Living environment means property, animals and plants, and their reproductive environments, that have a close relationship with the lives of humans.

V. Emissions standards means the maximum concentration or total quantity allowed for the presence of each type of air pollutant in waste gas emissions, or emissions quantity per unit of raw materials and components, fuel or products.

VI. Air quality standards means concentration limits for air pollutants in outdoor air.

VII. Air pollution control regions (herein referred to as control regions) means each class of control region delineated based on the demands placed upon air quality by land use within a region or in accordance with current air quality conditions.

VIII. Nature protection and conservation areas means ecological conservation areas, nature reserves, wildlife preserves and national forest preserves.

IX. Total quantity control means limiting measures that are formulated for total allowable emissions quantities of air pollutants within a certain area in order to effectively improve air quality.

$X$. Total quantity control zones means areas delineated in accordance with total quantity control requirements and based on topographical and meteorological conditions.

XI. Best available control technology means commercialized technology that provides the greatest feasible reduction in pollutant emissions quantities and that pollution sources, after taking into consideration energy, environmental and economic impacts, shall be required to adopt.

\section{Article 3}

"Competent authority" as referred to in this Act means the Environmental Protection Administration, Executive Yuan, at the central government level, the municipal government in special municipalities and the county or city government in counties or cities. 


\section{Article 4}

Competent authorities at all levels may designate or commission dedicated organizations to perform tasks related to air pollution research, training and control.

\section{Chapter 2 Air Quality Maintenance}

\section{Article 5}

The central competent authority shall delineate and officially announce each class of special municipality, county and city control region based on the demands placed upon air quality by land use or air quality conditions.

The control regions in the foregoing paragraph shall be divided into the following three classes.

I. Class 1 control regions means such areas as national parks and nature protection and conservation areas that are delineated in accordance with the law.

II. Class 2 control regions means areas that meet air quality standards, with the exception of Class 1 control regions.

III. Class 3 control regions means areas that do not meet air quality standards, with the exception of Class 1 control regions.

The central competent authority in consultation with the relevant agencies shall determine the air quality standards in the foregoing paragraph.

\section{Article 6}

Stationary pollution sources may not be newly added or modified within Class 1 control regions, with the exception of facilities for maintaining the livelihoods of residents within the region, facilities necessary for the operation and management of national parks, and national defence facilities.

Those newly added or modified stationary pollution sources within Class 2 control regions in which pollutant emissions quantities reach a certain scale shall be required to perform modelling and simulation for their pollutant emissions quantities in order to verify that these quantities will not exceed allowable pollutant increase limits within the control region in which the pollution source is located or within adjacent control regions in which air quality might also be affected.

Existing stationary pollution sources within Class 3 control regions shall reduce pollutant emissions quantities. Those newly added or modified stationary pollution sources within Class 3 control regions in which pollutant emissions quantities reach a certain scale shall employ best available control technology and shall also be required to perform modelling and simulation for their pollutant emissions quantities in order to verify that these quantities will not exceed allowable pollutant increase limits within the control region in which the pollution source is located or within adjacent control regions in which air quality might also be affected.

The central competent authority shall determine the pollutant emissions quantities, allowable pollutant increase limits for Class 2 and Class 3 control regions, air quality modeling and simulation standards, and the best available control technology in the two foregoing paragraphs.

\section{Article 7}

Special municipality, county and city competent authorities shall determine and officially announce air pollution control plans pursuant to the foregoing article, and shall evaluate, revise and improve said plans and submit said plans to the central competent authority for approval every two years. 
The central competent authority may, based on topographical and meteorological conditions, designate single or multiple special municipalities, counties or cities between which it is possible for air pollutants to circulate as total quantity control zones, determine total quantity control plans, and officially announce and implement total quantity controls.

Within a total quantity control zone that meets air quality standards, those newly installed or modified stationary pollution sources for which pollutant emissions quantities reach a certain scale shall be required to perform modelling and simulation for their pollutant emissions quantities in order to verify that these quantities will not exceed allowable pollutant increase limits within the zone.

Within a total quantity control zone that does not meet air quality standards: an existing stationary pollution source shall apply to the local competent authority for authorization of its pollutant emissions quantity and shall make reductions in accordance with the targets and deadlines the central competent authority has designated based on air quality requirements; and, newly installed or modified stationary pollution sources for which pollutant emissions quantities reach a certain scale shall employ best available control technology and obtain emissions quantities sufficient to offset pollutant emissions increases.

Those existing stationary pollution sources that, as a result of the adoption of control measures, achieve actual emissions reduction quantities greater than designated reduction quantities may bank, offset or trade the difference after authorization by the local competent authority.

The central competent authority in consultation with the relevant agencies shall determine the allowable pollutant increase limits in Paragraph 2, the scale of the pollutant emissions quantities in Paragraphs 2 and 3, the criteria for the authorization of the pollutant emissions quantities of existing stationary pollution sources in Paragraph 3, and the regulations for the authorization of the emissions reduction quantities difference for banking, offsetting or trading in the foregoing paragraph.

\section{Article 9}

For the purpose of offsetting pollutant emissions increases, the newly installed or modified stationary pollution sources in Paragraph 3 of the foregoing article shall obtain emissions quantities from the following sources.

I. Surplus emissions quantities that have been banked by stationary pollution sources in accordance with regulations

II. Banked emissions quantities the competent authority has released through auction

III. Emissions quantities that have been obtained through improvements to transportation vehicle use methods, the purchase of older vehicles or other methods of reducing emissions from mobile pollution sources

IV. Emissions quantities that have been obtained through emissions reductions achieved through street cleaning and sweeping

V. Other emissions quantities that have been authorized by the central competent authority

\section{Article 10}

The total quantity control plans of total quantity control zones that meet air quality standards shall include allowable pollutant increase limits, measures for avoiding the deterioration of air quality, rules for the approval of newly added or modified stationary pollution sources, organizational and operational methods, and other matters.

The total quantity control plans of total quantity control zones that do not meet air quality standards shall include pollutant types, quantity reduction targets, quantity reduction timetables, pollutant reduction quantities and timetables that the competent authorities of each special municipality, county and city within the control zone shall be required to implement, rules for the approval of newly added or modified stationary pollution sources, organizational and operational methods, and other matters. 


\section{Article 11}

Special municipalities, counties and cities within total quantity control zones shall determine and revise air pollution control plans in accordance with the total quantity control plans in the foregoing article.

For those air pollution control plans in the foregoing paragraph that are determined for total quantity control zones that do not meet air quality standards, the competent authority shall designate the stationary pollution sources that shall be required to reduce emissions quantities and reduction quantities and timetables in accordance with the regulations for pollutant reduction quantities and timetables that competent authorities shall be required to implement pursuant to the foregoing article.

\section{Article 12}

The central competent authority in conjunction with the Ministry of Economic Affairs shall officially announce and implement regulations related to total quantity control in Article 8 through the foregoing article on a stage-by-stage and zone-by-zone basis after the establishment of a checking system for pollution source emissions quantities and an emissions trading system.

\section{Article 13}

Competent authorities at all levels shall select appropriate locations for the installation of air quality monitoring stations and officially publish air quality conditions at regular intervals.

\section{Article 14}

Competent authorities at all levels and public and private premises shall promptly adopt emergency control measures when variations in meteorological conditions or other reasons cause there to be a concern of a serious deterioration in air quality. When necessary, competent authorities at all levels may issue air quality deterioration alerts and may prohibit or restrict the use of transportation vehicles, the emissions of air pollutants by public and private premises, and activities at government agencies and schools.

The central competent authority in conjunction with the relevant agencies shall determine the emergency control regulations for the serious deterioration of air quality in the foregoing paragraph.

\section{Article 15}

When developing special industrial parks, buffer zones and air quality monitoring facilities shall be planned and installed within the boundaries of the parks or in appropriate areas.

The central competent authority shall determine the categories, buffer zones and air quality monitoring facility standards for the special industrial parks in the foregoing paragraph.

\section{Article 16}

Competent authorities at all levels may collect air pollution control fees from stationary and mobile pollution sources that emit air pollutants. The targets of air pollution control fees are as follows.

I. Stationary pollution sources: fees shall be collected from the owners of the pollution source based on the types and quantity of air pollutants emitted; fees shall be collected from the actual user or manager if the owner of the source is not the user or manager; fees shall be collected from the construction project owner if the pollution source is a construction project; for substances designated and officially announced by the central competent authority, fees may be collected from the vendor or importer based on the sales volume of the substance.

II. Mobile pollution sources: fees shall be collected from the vendor or user based on the types and quantity of air pollutants emitted, or from the vendor or importer based on the type, composition and quantity of fuel.

For air pollution control fees, the central competent authority in consultation with the relevant agencies shall determine fee collection methods, calculation methods, payment procedures, payment deadlines, 
methods for the pursuit of insufficient payment, calculation methods for pollutant emissions quantities, and other binding fee collection regulation matters.

\section{Article 17}

The air pollution control fees in the foregoing article shall be collected by the central competent authority, with the exception of air pollution control fees for construction projects, which shall be collected by special municipality, county or city competent authorities. Sixty percent of the funds collected by the central competent authority from stationary pollution sources shall be allocated to the governments of the special municipalities, counties or cities in which said stationary pollution sources are located and shall be used for air pollution control work; however, if the central competent authority determines that the results of the air quality maintenance or improvement plans implemented by a special municipality, county or city government are inadequate or if the funds are not used pursuant to Article 18, the central competent authority may consider reducing the amount of funds to be allocated.

The central competent authority in consultation with the relevant agencies shall determine the fee rates for the fees in the foregoing paragraph based on current air quality conditions, pollution sources, pollutants, fuel type and pollution control costs.

After the implementation of the fee rate in the foregoing paragraph for one full year, local competent authorities in total quantity control zones may, taking into consideration environmental and air quality conditions in the control zone at issue, regularly submit a recommended fee rate within a range of plus or minus $30 \%$ of the fee rate in the foregoing paragraph. This recommended fee rate shall be submitted to the central competent authority for review, approval and official announcement.

\section{Article 18}

Air pollution control fees shall be provided exclusively for air pollution control uses. The matters for which these fees may be disbursed are as follows.

I. Matters concerning the implementation of air pollution control work by competent authorities

II. Matters concerning the inspection of air pollution sources and the auditing of the implementation and efficacy of such inspections

III. Matters concerning subsidies and incentives for the performance of air pollution abatement work by each category of pollution source

IV. Matters concerning the commissioning and subsidizing of analysis laboratories for the performance of motor vehicle emissions testing

V. Matters concerning the commissioning or subsidizing of professional organizations for the performance of the testing, guidance and evaluation of stationary pollution sources

VI. Matters concerning air pollution control technology research and development and strategy formulation

VII. Matters concerning international environmental protection work involving air pollution

VIII. Matters concerning air quality monitoring and the auditing of the implementation and efficacy of such monitoring

IX. Matter concerning the expenses related to the collection of air pollution control fees

$X$. The hiring of personnel required for work related to air pollution control

XI. Related matters concerning air pollution health risk assessments and management.

XII. Matters concerning incentives for promoting the use of clean energy and related research and development 
XIII. Other matters concerning air pollution control work

For the air pollution control fees in the foregoing paragraph, competent authorities may establish funds for the management and utilization of these fees and fund management committees for the supervision and operation of these funds. Scholars, experts and environmental group representatives shall account for at least two-thirds of the members of these committees, and environmental group representatives may not account for less than one-ninth of the members of these committees.

The Executive Yuan and special municipality, county and city competent authorities shall respectively determine regulations for the revenues and expenditures, safekeeping and utilization of the funds in the foregoing paragraph.

Competent authorities at all levels shall, for all incentives and subsidies related to the air pollution control fees in Paragraph 1, determine regulations for targets, application qualifications, review procedures, the revocation, cancellation and compensation of incentives and subsidies, and other binding matters.

\section{Article 19}

Those public and private premises with stationary pollution sources that are able to effectively reduce pollutant emission quantities to a certain level due to the implementation of pollution control and quantity reduction measures may apply to the competent authority for incentives; those that have already paid air pollution control fees pursuant to Article 16, Paragraph 1 may apply to the competent authority for air pollution control fee exemptions.

The central competent authority in consultation with the relevant agencies shall, for the air pollution control fee exemptions and incentives in the foregoing paragraph, determine management regulations for targets, application qualifications, review procedures, revocation, cancellation, compensation and other binding matters.

\section{Chapter 3 Control}

\section{Article 20}

Public and private premises with stationary pollution sources that emit air pollutants shall comply with emissions standards.

The central competent authority in consultation with the relevant agencies shall determine the emissions standards in the foregoing paragraph based on specially designated industry categories, facilities, pollutant items or areas.Special municipality, county and city competent authorities may draft more stringent individual emissions standards due to special needs and submit these standards to the central competent authority for approval in consultation with the relevant agencies.

\section{Article 21}

Those public and private premises possessing stationary pollution sources designated and officially announced by the central competent authority shall report the annual air pollutant emissions quantities of their stationary pollution sources for the previous year to the local competent authority before the end of January each year.

The central competent authority shall determine regulations for the calculation, reporting content, procedures and methods, checking, and other binding matters for the annual air pollutant emissions quantities of stationary pollution sources in the foregoing paragraph.

\section{Article 22}

Those public and private premises possessing stationary pollution sources designated and officially announced by the central competent authority shall complete the installation of automatic monitoring 
facilities by the designated deadline in order to continuously monitor their operations or air pollutant emissions conditions, and shall apply to the competent authority for authorization; those that have been designated and officially announced as being required to connect via the Internet shall complete the connection of their monitoring facilities via the Internet to the competent authority by the designated deadline.

With the exception of the pollution sources in the foregoing paragraph, the competent authority may, when it deems necessary, designate and officially announce whether a pollution source shall perform regular analysis on its own or shall commission an analysis laboratory to conduct such analysis.

Records of the results of the monitoring and analysis in the two foregoing paragraphs shall be maintained and shall be reported to the local competent authority in accordance with regulations; the central competent authority shall determine management regulations for recordkeeping, reporting, preservation, Internet connection standards, installation completion, Internet connection deadline and other binding matters for the results of monitoring and analysis

\section{Article 23}

Public and private premises shall effectively collect each type of air pollutant and maintain the normal operation of their air pollution control facilities and monitoring facilities; the maximum operating quantity of their stationary pollution sources may not exceed the maximum treatment capacity of their air pollution control facilities.

The central competent authority shall determine management regulations for the specifications, installation, operation, inspection, service, recordkeeping and other binding matters for stationary pollution sources and their air pollutant collection facilities, control facilities and monitoring facilities.

\section{Article 24}

Those public and private premises possessing stationary pollution sources designated and officially announced by the central competent authority shall, prior to installation or modification, submit air pollution control plans to the special municipality, county or city competent authority or other government agency commissioned by the central competent authority in order to apply for the issuance of installation permits, and shall perform installation or modification pursuant to the permit contents.

After the installation or modification of the stationary pollution sources in the foregoing paragraph, public and private premises shall submit verification documents that demonstrate compliance with the regulations of this Act to the special municipality, county or city competent authority or other government agency commissioned by the central competent authority in order to apply for the issuance of operating permits, and shall perform operations pursuant to the permit contents.

The central competent authority shall determine management regulations for the application, review procedures, issuance, cancellation, revocation, granting and suspension of commissions by the central competent authority, and other binding matters for installation and operating permits for stationary pollution sources.

\section{Article 25}

Public and private premises shall reapply for the issuance of installation and operating permits due to relocation or a change of industry category.

Those public and private premises that have already obtained an operating permit and for which the official announcement and implementation of total quantity controls by the central competent authority or revisions made by the competent authority in accordance with the standards of the issued operating permit causes the operating permit contents to be no longer in compliance with regulations shall reapply for the issuance of an operating permit to the special municipality, county or city competent authority or other government agency commissioned by the central competent authority by the deadline officially announced 
by the central competent authority.

\section{Article 26}

The air pollution control plan in Article 24, Paragraph 1 shall be signed by a legally registered and practicing environmental engineer or other relevant professional engineer.

Those within government agencies, public enterprises and public juridical persons subject to the foregoing paragraph that have legally obtained certification as an engineer in the foregoing paragraph may perform the signature work.

\section{Article 27}

A public or private premises possessing multiple stationary pollution sources that emit the same air pollutants may apply to the special municipality, county or city competent authority concerning improvements to its total quantity and concentration of air pollutant emissions; after review and approval, the emissions of its individual pollution sources may be exempt from the restrictions of the emissions standards determined pursuant to Article 20.

The public and private premises in the foregoing paragraph shall adopt the total quantity and concentration limits for air pollutants approved by the special municipality, county or city competent authorities as their emissions standards.

The central competent authority shall determine management regulations for the application, review procedures, approval, cancellation, revocation and other binding matters for the total quantity and concentration of air pollutant emissions in Paragraph 1.

\section{Article 28}

Those vendors or users of bituminous coal, petroleum coke or other substances prone to cause air pollution shall first submit the relevant documents in order to apply to the special municipality, county or city competent authority; the sale or use of these substances may begin only after a review of qualifications and the issuance of a permit; records of the sale and use of these substances shall be maintained and reported to the local competent authority in accordance with regulations.

The central competent authority in consultation with the relevant agencies shall officially announce the substances that are prone to cause air pollution in the foregoing paragraph.

The central competent authority in consultation with the relevant agencies shall determine management regulations for the application, review procedures, issuance, revocation, cancellation, recordkeeping, reporting and other binding matters for the sales or use permits in Paragraph 1.

\section{Article 29}

The validity time period for permits issued pursuant to Article 24, Paragraphs 1 and 2 and Paragraph 1 of the foregoing article shall be five years. Those that still wish to continue to use their permits upon expiration shall submit a permit extension application to the special municipality, county or city competent authority or other government agency commissioned by the central competent authority between three to six months prior to expiration. Each extension may not exceed 5 years.

The special municipality, county or city competent authority or other government agency commissioned by the central competent authority shall reject the applications of those public and private premises for which permit extension application documents fail to meet regulations or are not corrected by the permit expiration deadline; those public and private premises that fail to apply for extensions between three to six months prior to the permit expiration deadline and for which the special municipality, county or city competent authority or other government agency commissioned by the central competent authority has yet to make a decision concerning approval or rejection by the date of the permit expiration deadline shall suspend installation, modification, operations, sales or use on the date of the permit expiration deadline; the 
permits of those public and private premises that fail to apply for extensions prior to the permit expiration deadline shall lose validity on the date of the permit expiration deadline; public or private premises shall reapply for an installation, operating, sales or use permit if they need to continue installation, modification, operation, sales or use.

The special municipality, county or city competent authority or other government agency commissioned by the central competent authority shall, based on actual requirements, approve the period of validity of permits for those stationary pollution sources installed and operating for less than five years or located in total quantity control zones.

\section{Article 30}

The central competent authority may prohibit or restrict substances that are prone to cause air pollution that are controlled under international environmental protection conventions and the manufacture, import, export, sale or use of products manufactured from or filled with such substances.

The central competent authority in consultation with the relevant agencies shall officially announce the substances and products in the foregoing paragraph; the central competent authority in consultation with the relevant agencies shall determine management regulations for the permit application, review procedures, cancellation, recordkeeping, reporting and other binding matters for the manufacture, import, export, sale or use of these substances and products.

\section{Article 31}

The following acts are prohibited within each class of control region or within total quantity control zones.

I. Engagement in burning, melting, refining, grinding, casting, conveyance or other operation that causes the production of significant particulate pollutants that are dispersed into the air or onto the property of others

II. Engagement in construction projects, piling of powdered or granular materials, transportation of construction materials or waste, or other industrial processes without appropriate control measures that causes airborne dust or polluted air

III. Placement, mixing, stirring, heating or baking of substances, or engagement in other operations that causes noxious odors or toxic gases

IV. Use, conveyance or storage of organic solvents or other volatile substances that causes noxious odors or toxic gases

V. Food preparation by the food and beverage industry that causes the dispersal of oily smoke or noxious odors

VI. Other air polluting acts officially announced by the competent authority

Air polluting acts in the foregoing paragraph means acts in which air pollutants are not emitted through exhaust pipes.

The central competent authority shall determine the implementation criteria for the control of the acts in Paragraph 1.

\section{Article 32}

When the stationary pollution sources of a public or private premises emit a large quantity of air pollutants due to a sudden accident, the statutory responsible person shall promptly adopt emergency response measures and shall notify the local competent authority within one hour.

Under the circumstances in the foregoing paragraph, the competent authority may, in addition to ordering the public or private premises to adopt necessary measures, order the public or private premises to 
suspend the operation of the stationary pollution sources at issue.

\section{Article 33}

Public and private premises that have been designated and officially announced by the central competent authority shall establish dedicated air pollution control units or personnel positions.

The dedicated personnel in the foregoing paragraph shall comply with the qualifications designated by the central competent authority and undergo training in order to obtain a qualification certificate.

The central competent authority in consultation with the relevant agencies shall determine management regulations for the establishment of dedicated units and personnel positions, the qualifications and training of dedicated personnel, the obtaining, revocation and cancellation of qualification certificates, and other binding matters.

\section{Article 34}

Air pollutants emitted by transportation vehicles shall meet emissions standards.

The central competent authority in consultation with the relevant agencies shall determine the emissions standards in the foregoing paragraph.

\section{Article 35}

The owners of transportation vehicles shall maintain the effective operation of the air pollution control equipment of their vehicle and may not remove or modify this equipment.

The type, specifications and labelling of the transportation vehicle air pollution control equipment in the foregoing paragraph shall meet the regulations of the central competent authority.

\section{Article 36}

The manufacture, import, sale or use of fuel supplied for use in transportation vehicles shall comply with the composition standards and property standards for fuel types determined by the central competent authority.However, fuel supplied exclusively for export shall not be subject to this restriction.

The fuel manufacturers in the foregoing paragraph shall obtain permits issued by the central competent authority before the fuel they produce may be sold domestically; importers shall obtain permit documents issued by the central competent authority before they may apply to the petroleum industry industry competent authority for import approval documents. Manufacturers or importers shall perform composition and property analysis on each batch (shipment) of fuel and maintain records which shall be reported to the central competent authority.

The central competent authority in consultation with the relevant agencies shall determine management regulations for the fuel types, composition standards and property standards in Paragraph 1 and the permitting, revocation, cancellation, reporting of records and other binding matters for the sale and import in the foregoing paragraph.

\section{Article 37}

For those in-use motor vehicles that have undergone random testing of air pollutants emissions by the central competent authority and that are determined to be unable to meet air pollution emissions standards for transportation vehicles due to poor design or assembly, the central competent authority shall order the manufacturer or importer to recall for repair within a limited time period all units of the model of the motor vehicle at issue that have already been sold; the central competent authority shall suspend the manufacture, import and sales of those manufacturers or importers that fail to comply with this order by the deadline.

The central competent authority in consultation with the relevant agencies shall determine regulations for motor vehicle recall and correction. 


\section{Article 38}

Domestically manufactured and marketed motor vehicles shall obtain central competent authority issued vehicle model exhaust testing compliance verification before they may apply for license plates; central competent authority issued vehicle model exhaust testing compliance verification and central competent authority certification and authorization shall be obtained for import motor vehicles before applications may be submitted for license plates.

The central competent authority in consultation with the relevant agencies shall determine regulations for the certification and authorization of imported motor vehicle air pollutants in the foregoing paragraph.

\section{Article 39}

The central competent authority in conjunction with the Ministry of Transportation and Communications shall determine regulations for the issuance, revocation and cancellation of the vehicle model exhaust testing compliance verification for motor vehicles, and testing and treatment regulations for the air pollutants emissions of transportation vehicles.

\section{Article 40}

In-use motor vehicles shall undergo regular air pollutant emissions testing; the owner of a motor vehicle for which testing reveals a failure to comply with the emissions standards in Article 34 shall make repairs and apply for retesting within one month; the owner of a motor vehicle that has not undergone regular testing or for which retesting still reveals a failure to comply may be prohibited from renewing their vehicle license.

The central competent authority shall determine and officially announce the targets, regions, frequency and deadlines for the performance of the testing in the foregoing paragraph.

The central competent authority shall determine management regulations for the conditions, facilities, computer software, testing personnel qualifications, installation authorization, revocation, cancellation, checking, suspension of testing and other binding matters for the establishment of air pollutant emissions testing stations for in-use motor vehicles.

\section{Article 41}

Competent authorities at all levels may perform irregular air pollutant emissions testing or inspections of in-use transportation vehicles at car parks, at airports, at stations, on roadways, in port zones, on water bodies or at other appropriate locations, or may notify transportation vehicles for which there is a concern of polluting to undergo testing at a designated location by a designated deadline.

The central competent authority in consultation with the relevant agencies shall determine regulations for the irregular air pollutant emissions testing of in-use motor vehicles.

\section{Article 42}

Those in-use motor vehicles for which air pollutant emissions are determined through visual determination, visual inspection or remote sensing performed by competent authority inspection personnel to fail to meet the emissions standards in Article 34 or the remote sensing screening standards officially announced by the central competent authority shall be repaired and undergo testing at a designated location by the deadline designated in the competent authority notification.

Citizens may report the air pollutant emissions of in-use motor vehicles to the competent authority; those vehicles which have been reported and notified by the competent authority shall undergo testing at a designated location by a designated deadline; the central competent authority shall determine regulations for reporting and incentives.

\section{Article 43}


Competent authorities at all levels may dispatch personnel bearing identification documents to inspect or appraise the air pollutant emissions, air pollution collection facilities, control facilities and monitoring facilities of public and private premises or transportation vehicles, or the quality of fuel that is produced, stored or used by public and private premises or transportation vehicles, and order the provision of relevant information.

Orders to provide information pursuant to the regulations in the foregoing paragraph shall be conducted in conjunction with military authorities when military secrets are involved.

The inspections, appraisals and orders in the two foregoing paragraphs may not be evaded, obstructed or refused.

Public and private premises shall possess equipment for the facilitation of the implementation of the inspections and appraisals in Paragraph 1; the central competent authority shall officially announce the specifications for these facilities.

\section{Article 44}

Analysis and testing organizations may perform analysis and testing work pursuant to this Act only after obtaining an approved permit from the central competent authority.

The central competent authority shall determine management regulations for the required conditions and facilities; the qualifications of analysis personnel; the application, review, issuance, replacement, revocation, cancellation, suspension of business, resumption of business, checking and evaluation procedures for permits; and other binding matters for the analysis laboratories in the foregoing paragraph.

The central competent authority shall determine all analysis methods in this Act.

\section{Article 45}

Each industry competent authority shall provide guidance for the improvement of all types of pollution sources.

\section{Chapter 4 Penal Provisions}

\section{Article 46}

Those that violate Article 32, Paragraph 1 by failure to adopt emergency response measures promptly or that fail to comply with orders issued by the competent authority pursuant to Article 32, Paragraph 2, and thereby cause human death, shall be punished by life imprisonment or a minimum of seven years imprisonment and may be fined a maximum of NT\$5 million; those that cause severe injury shall be punished by three to ten years imprisonment and may be fined a maximum of NT\$3 million; those that cause harm to human health such that it leads to illness shall be punished by a maximum of five years imprisonment and may be fined a maximum of NT $\$ 2$ million.

\section{Article 47}

Those that have reporting obligations pursuant to this Act that knowingly report false information or keep false records of their operations shall be punished by a maximum of three years imprisonment, detention and/or a fine of NT\$200,000 to NT\$1 million.

\section{Article 48}

Those that lack air pollution control equipment and burn substances prone to cause particular harm to health shall be punished by a maximum of three years imprisonment, detention and/or a fine of NT $\$ 200,000$ to NT\$1 million.

The central competent authority shall officially announce the substances prone to cause particular 
harm to health and the air pollution control equipment in the foregoing paragraph.

\section{Article 49}

For those circumstances in which a public or private premises fails to comply with an order to suspend work or suspend business issued by the competent authority pursuant to this Act, the statutory responsible person shall be punished by a maximum of one years imprisonment, detention and/or a fine of NT\$200,000 to NT\$1 million.

Those that fail to comply with an order to suspend the operation of a stationary pollution source issued by the competent authority pursuant to Article 32, Paragraph 2 or Article 60, Paragraph 2 or an order to suspend activities issued by the competent authority pursuant to Article 60, Paragraph 2 shall be punished by a maximum of one years imprisonment, detention and/or a fine of NT\$200,000 to NT\$1 million.

\section{Article 50}

For those circumstances in which the representative of a juridical person, or an agent, employee or other working personnel of a juridical person or natural person violates, due to the performance of business activities, Article 46, Article 47, Article 48, Paragraph 1 or Article 49, Paragraph 2, in addition to the perpetrator being punished pursuant to the regulations of each article violated, said juridical person or natural person shall also be fined pursuant to the regulations of each article violated.

\section{Article 51}

Those public or private premises that fail to reduce pollutant emissions quantities pursuant to Article 8, Paragraph 3 or that violate the regulations for the authorization of the emissions reduction quantities difference for banking, offsetting or trading that are determined pursuant to Article 8, Paragraph 5 shall be fined NT\$20,000 to NT\$200,000; those violators that are industrial or commercial facilities or sites shall be fined NT\$100,000 to NT\$1 million.

Those fined pursuant to the foregoing paragraph shall also be notified to make corrections or make improvements within a limited time period; those that have still failed to make corrections or make improvements by the deadline shall be issued consecutive daily fines; in those severe circumstances, orders may be issued for the suspension of work or suspension of business and, when necessary, operating permits may be cancelled or orders issued for the termination of business.

\section{Article 52}

Those public or private premises that violate Article 6, Paragraph 1 shall be fined NT\$1 million and ordered to suspend work.

\section{Article 53}

Those public or private premises that violate Article 14, Paragraph 1 or the regulations determined pursuant to Article 14, Paragraph 2 shall be fined NT\$1 million; in those severe circumstances, the public or private premises may be ordered to suspend work or suspend business.

For those circumstances in which the user of a transportation vehicle violates Article 14, Paragraph 1 or the regulations determined pursuant to Article 14, Paragraph 2, the user or owner shall be fined NT\$30,000.

\section{Article 54}

For those circumstances in which Article 15 is violated, the developer shall be fined NT\$500,000 to NT\$5 million and notified to make improvements within a limited time period; those that have still failed to complete improvements by the deadline shall be issued consecutive daily fines. 


\section{Article 55}

For those that fail to pay fees pursuant to the fee collection regulations determined pursuant to Article 16, Paragraph 2 by the deadline, an overdue fine, which shall be assessed at a rate of $0.5 \%$ of the overdue amount for each day the fees are overdue, shall be paid together with the overdue fees; those that have still failed to pay fees 30 days after the deadline shall be fined NT\$1 million and ordered to pay within a limited period; those that have still failed to pay fees by the deadline shall be referred for compulsory enforcement in accordance with the law.

For the fees and overdue fines that shall be required to be paid in the foregoing paragraph, interest shall be accrued daily from the day after the overdue deadline to the date of payment based on the fixed annual interest rate for a one-year time deposit with the Directorate General of the Postal Remittances and Savings Bank on the date of payment.

\section{Article 56}

Those public or private premises that violate Article 20, Paragraph 1; Article 21; Article 22, Paragraphs 1, 2 or 3; Article 23; Article 24, Paragraphs 1 or 2 by failure to perform installation, modification or operation pursuant to permit contents, Article 25; the emissions standards approved pursuant to Article 27, Paragraph 2; or the management regulations determined pursuant to Article 24, Paragraph 3 or Article 27, Paragraph 3 shall be fined NT\$20,000 to NT\$200,000; those violators that are industrial or commercial facilities or sites shall be fined NT\$100,000 to NT\$1 million.

Those fined pursuant to the foregoing paragraph shall also be notified to make corrections or make improvements within a limited time period; those that have still failed to make corrections or make improvements by the deadline shall be issued consecutive daily fines; in those severe circumstances, orders may be issued for the suspension of work or suspension of business and, when necessary, operating permits may be cancelled or orders issued for the termination of business.

For those circumstances in Paragraph 1 in which a single public or private premises has multiple stationary pollution sources or a stationary pollution source emits multiple types of pollutants, fines shall be issued separately for each stationary pollution source or each type of pollutant.

\section{Article 57}

Those public or private premises that fail to obtain permits pursuant to Article 24, Paragraphs 1 or 2 and directly perform installation, modification or operation shall be fined NT $\$ 20,000$ to NT $\$ 200,000$; those violators that are industrial or commercial facilities or sites shall be fined NT\$100,000 to NT\$1 million and ordered to suspend work and to apply for and obtain an installation or operating permits within a limited time period.

\section{Article 58}

Those that violate Article 28, Paragraph 1 or the management regulations determined pursuant to Article 28, Paragraph 3 shall be fined NT\$1 million.

Those fined pursuant to the foregoing paragraph shall also be notified to make corrections or report within a limited time period; those that have still failed to comply by the deadline shall be issued consecutive daily fines; in those severe circumstances, orders may be issued for the suspension of work or suspension of business and, when necessary, sales or use permits may be cancelled or orders issued for the termination of business.

\section{Article 59}

Those that violate the management regulations determined pursuant to Article 30, Paragraph 2 shall be fined NT\$100,000 to NT\$1 million and notified to make corrections or report within a limited time period; those that have still failed to comply by the deadline shall be issued consecutive daily fines; in those severe circumstances, orders may be issued for the suspension of work or suspension of business and, when 
necessary, sales or use permits may be cancelled or orders issued for the termination of business.

Those that violate the import or export regulations of the management regulations determined pursuant to Article 30, Paragraph 2 shall be punished by six months to five years imprisonment and may be fined NT\$300,000 to NT\$1.5 million.

\section{Article 60}

Those that violate one of the circumstances in the subparagraphs under Article 31, Paragraph 1 shall be fined NT\$1 million.

Those fined pursuant to the foregoing paragraph shall also be notified to make improvements within a limited time period; those that have still failed to complete improvements by the deadline shall be issued consecutive daily fines; in those severe circumstances, orders may be issued for the suspension of activities or the suspension of the operation of pollution sources, or issued for the suspension of work or the suspension of business, and, when necessary, operating permits may be cancelled or orders issued for the termination of business.

\section{Article 61}

Those that violate Article 32 shall be fined NT $\$ 100,000$ to NT\$1 million; in those severe circumstances, orders may be issued for the suspension of work or suspension of business and, when necessary, operating permits may be cancelled or orders issued for the termination of business

\section{Article 62}

Those public or private premises that violate Article 33, Paragraph 1 or the management regulations determined pursuant to Article 33, Paragraph 3 shall be fined NT\$1 million and notified to make corrections or improvements within a limited period; those that have still failed to make corrections or complete improvements by the deadline shall be issued consecutive daily fines.

Those dedicated air pollution control personnel that violate the management regulations determined pursuant to Article 33, Paragraph 3 shall be fined NT\$100,000 and, when necessary, the central competent authority may cancel their dedicated personnel qualification certificates.

\section{Article 63}

For those circumstances in which Article 34, Paragraph 1 or Article 35 is violated, the user or owner shall be fined NT\$60,000 and notified to make improvements within a limited period; those that have still failed to complete improvements by the deadline shall be fined per violation.

The central competent authority in conjunction with the Ministry of Transportation and Communications shall determine the fine standards for the foregoing paragraph.

\section{Article 64}

For those circumstances in which Article 36, Paragraphs 1 or 2 or the management regulations determined pursuant to Article 36, Paragraph 3 is violated, the user shall be fined NT\$1 million and notified to make improvements within a limited period; those that have still failed to complete improvements by the deadline shall be issued consecutive daily fines.

\section{Article 65}

Those manufacturers or importers that violate Article 37 by failure to issue recall notifications shall be fined NT\$100,000 per vehicle.

\section{Article 66}

Those that violate the management regulations determined pursuant to Article 39 shall be fined 
NT\$200,000 and notified to make corrections or improvements within a limited period; those that have still failed to make corrections or complete improvements by the deadline shall be fined per violation.

\section{Article 67}

For those that fail to undergo regular air pollutant emissions testing pursuant to Article 40, the motor vehicle owner shall be fined NT\$15,000.

Those motor vehicles for which testing has revealed a failure to meet emissions standards and that have failed to undergo repair or retesting within one month or for which retesting after the deadline reveals a failure to meet standards shall be fined NT\$30,000.

Those that violate the management regulations determined pursuant to Article 40, Paragraph 3 shall be fined NT\$15,000 to NT\$60,000 and notified to make corrections or make improvements within a limited time period; those that have still failed to make corrections or complete improvements by the deadline shall be fined per violation; in those severe circumstances, orders shall be issued for the suspension of testing operations and authorization certificates may be cancelled.

\section{Article 68}

For those that do not undergo testing pursuant to Article 42 or for which testing reveals a failure to meet emissions standards, the motor vehicle user or owner shall be fined NT $\$ 60,000$

\section{Article 69}

For those circumstances in which there is evasion, obstruction or refusal of the inspections, appraisals or orders required or issued pursuant to Article 43, Paragraph 1 or a failure to possess the facilities required pursuant to Article 43, Paragraph 4, public or private premises shall be fined NT\$100,000, and each may be fined per violation and be subject to the compulsory enforcement of inspection or appraisal.

\section{Article 70}

Those that violate Article 44, Paragraph 1 or the management regulations determined pursuant to Article 44, Paragraph 2 shall be fined NT\$200,000 to NT\$1 million and notified to make corrections or make improvements within a limited time period; those that have still failed to make corrections or make improvements by the deadline shall be issued consecutive daily fines; in those severe circumstances, orders may be issued for the suspension of business and, when necessary, permits may be cancelled or orders issued for the termination of business.

\section{Article 71}

Those that fail to submit verification documents for already planned and installed buffer zones and air quality monitoring facilities that meet emissions standards, fuel composition standards and property standards or other regulations to the competent authority for checking by the deadline for the notification to make improvements issued pursuant to this Act shall be considered to have failed to complete improvements.

The central competent authority shall determine starting dates, temporary suspension dates, termination dates, improvement completion verification checking methods, enforcement methods for regulations and orders, and other binding matters for the consecutive daily fines of those that fail to complete corrections, reporting or improvements by the deadlines of the regulations of this Act.

\section{Article 72}

The period for making corrections, making improvements or reporting for those notified pursuant to this Act to make corrections, make improvements or report within a limited period shall be limited to ninety days. Those unable to complete improvements by the improvement deadline due to natural disaster or other force majeure shall continue to make improvements after the reason ends and shall, within 15 days, apply to 
the competent authority for the approval of an improvement deadline by submitting a written explanation of cause and relevant information.

Those stationary pollution sources of public or private premises and those manufacturers or importers responsible for the recall and correction of motor vehicles that are unable to complete improvements by the deadline in the foregoing paragraph may, within 30 days after receiving notification, submit specific improvement plans to the competent authority in order to apply for extensions; the competent authority shall approve the improvement deadline based on actual conditions; the maximum extension may not exceed one year; the competent authority may terminate promptly the improvement deadline of those that are verified through checking to have failed to strictly carry out implementation in accordance with the improvement plan and may punish the violator severely.

Those stationary pollution sources and transportation vehicles that, during the improvement period, emit pollutants in excess of emissions concentrations or emissions quantities for which fines were issued originally shall be fined per violation.

\section{Article 73}

Unless other regulations apply, the penalties determined pursuant to this Act shall be assessed by the Environmental Protection Administration, Executive Yuan, at the central government level, the municipal government in special municipalities and the county or city government in counties or cities.

\section{Article 74}

For fines issued pursuant to this Act, those that have been notified to make payments within a limited period and have still failed to make payments by the deadline shall be referred for compulsory enforcement in accordance with the law.

When the owner or user of a motor vehicle refuses to pay a fine, the competent authority may request the cooperation of the highway supervisory authority in suspending the movement of the vehicle.

\section{Article 75}

The amount of fines for those fined pursuant to this Act shall be determined in accordance with the degree of pollution, pollution characteristics and the degree of harm caused by the pollution.

The central competent authority shall determine the fine determination criteria in the foregoing paragraph.

\section{Chapter 5 Supplementary Provisions}

\section{Article 76}

Those public or private premises that possess a stationary pollution source designated and officially announced pursuant to Article 24, Paragraph 1, and for which the stationary pollution source at issue was installed prior to the official announcement, shall apply for an operating permit pursuant to Article 24, Paragraph 2 of this Act within two years of the day of the official announcement.

\section{Article 77}

When the malfunction of facilities related to a stationary pollution source causes the violation of this Act, those public or private premises that promptly implement response measures and handle the malfunction pursuant to the following regulations may be exempt from penalties imposed pursuant to this Act

I. Report to the local competent authority within one hour of the malfunction.

II. Repair the facilities or suspend operations within 24 hours of the malfunction. 
III. Submit a written report to the local competent authority within 15 days of the malfunction.

\section{Article 78}

Those public or private premises that, prior to engagement in the following acts, have already applied to the local competent authority and received authorization shall be exempt from penalties imposed pursuant to this Act.

I. Fire drills

II. The burning of infected animals or plants for the emergency control of the spread of infectious diseases

III. Other acts officially announced by the central competent authority

When meteorological conditions are disadvantageous to the dispersal of pollutants, there is a trend towards a significant deterioration in air quality, or public or private premises fail to perform implementation in accordance with authorization contents, the competent authority may order the postponement or suspension of the implementation of the authorized acts in the foregoing paragraph.

\section{Article 79}

Competent authorities at all levels shall collect such official fees as review fees, testing fees and certificate fees for the performance of testing, the issuance of permits and certificates, and the review of and permitting for all applications accepted pursuant to this Act.

The central competent authority in consultation with the relevant agencies shall determine fee collection standards for the foregoing paragraph.

\section{Article 80}

Victims of air pollution may apply to the central or local competent authority for appraisal of the reason for being victimized; the central or local competent authority may, after investigating the reason in conjunction with the relevant agencies, order those that emit air pollutants to make improvements promptly and the victims may seek appropriate compensation.

When, in those circumstances in which an agreement is achieved for the compensation in the foregoing paragraph, the fulfillment of the agreement is refused, the victim may directly submit a request to a court for compulsory enforcement.

\section{Article 81}

When a public and private premises violates this Act or related orders determined pursuant to the authorization of this Act and the competent authority is negligent in enforcement, victims or public interest groups may notify the competent authority in writing of the details of the negligent enforcement.For those competent authorities that have still failed to carry out enforcement in accordance with the law within sixty days after receipt of the written notification, the victims or public interest groups may name the competent authority at issue as a defendant and file a lawsuit directly with an administrative court based on the negligent behavior of the competent authority in the execution of its duties in order to seek a ruling ordering the competent authority to execute its duties.

When issuing a verdict on the lawsuit in the foregoing paragraph, the administrative court pursuant to its authority may order the defendant agency to pay the appropriate lawyer fees, detection and appraisal fees and other litigation costs to plaintiffs that have made specific contributions to the maintenance of air quality.

The central competent authority in consultation with the relevant agencies shall officially announce the format of the written notification in Paragraph 1. 
The severe circumstances referred to in Article 51, Article 53, Article 56, and Article 58 through Article 61 in this Act mean one of the following circumstances.

I. Those circumstances in which a pollution source that fails to legally register or obtain permission violates the regulations of this Act

II. Those circumstances in which consecutive daily fines have been issued for over 90 days

III. Those circumstances in which a violator, after punishment, voluntarily reports the suspension of work and the implementation of improvements, and verification checks prove this to be untruthful

IV. Those circumstances in which a violator, having been notified twice within one year to make improvements within a limited period, still continues to violate the regulations of this Act

V. Those circumstances in which the emission of large quantities of air pollutants seriously impacts the air quality of nearby areas

VI. Those circumstances in which there is concern of the endangerment of public health due to the emission of air pollutants that contain toxic substances

VII. Other acts that seriously impact the air quality of nearby areas

\section{Article 83}

Those public or private premises that are ordered by the competent authority to suspend the operation of a pollution source, suspend work or business pursuant to Article 51, Paragraph 2, Article 53, Paragraph 1, Article 56, Paragraph 2, Article 58, Paragraph 2, Article 59, Paragraph 1, Article 60, Paragraph 2 or Article 61 in this Act, or those that have been ordered by the competent authority to make improvements and that voluntarily report the suspension of work or business, shall, prior to the resumption of the operation of the pollution source or the resumption of business or work, submit a trial operation plan and apply to the competent authority for trial operation, and may only perform trial operation after approval by the competent authority; the public or private premises shall submit verification documents demonstrating compliance with emissions standards by the trial operation deadline, and may only resume operation or resume work or business after evaluation by the competent authority demonstrates compliance; the central competent authority shall determine trial operation, evaluation and other binding matters for public or private premises.

\section{Article 84}

For all types of pollution sources, those that have an impact on schools shall be punished severely.

\section{Article 85}

The central competent authority shall determine the enforcement rules of this Act.

\section{Article 86}

This Act shall take effect on the date of promulgation.

The articles of this Act revised on May 5, 2006 shall take effect on July 1, 2006. 